\title{
Tumor suppression without differentiation or apoptosis by antisense cyclin D1 gene transfer in K1735 melanoma involves induction of p53, p21WAF1 and superoxide dismutases
}

\author{
$M_{\text {Rieber }}^{*, 1}$ and M Strasberg Rieber ${ }^{1}$ \\ 1 Instituto Venezolano de Investigaciones Cientificas (IVIC), Centre of \\ Microbiology \& Cell Biology, Tumor Cell Biology Laboratory, Apartado 21827, \\ Caracas 1020 A, Venezuela \\ * Corresponding author: M Rieber, Instituto Venezolano de Investigaciones \\ Cientificas (IVIC), Centre of Microbiology \& Cell Biology, Apartado 2187, Km II \\ Carretera Panamericana, Caracas 1020A, Venezuela Fax 582-504 1382; \\ E-mail: mrieber@pasteur.ivic.ve
}

Received 16.6.99; revised 8.9.99; accepted 30.9.99

Edited by $\mathrm{C}$ Thiele

\begin{abstract}
In mammalian cells, terminal differentiation is mutually exclusive with proliferation. However, resistance to differentiation-inducing therapy requires alternative strategies to control poorly responsive tumors. We now show that retroviral transfer of the antisense cyclin D1 gene to differentiationrefractory K1735 melanoma leads to loss of in vivo tumorigenicity, shortened replicative ability, induction of the tumor suppressor p53 protein and of the cdk-inhibitor p21WAF1, increased $\beta$-galactosidase pH 6.0 activity, and elevation in the ratio of superoxide dismutases to peroxidases, all properties associated with replicative senescence. However, pigmentation and tyrosinase expression, characteristic of differentiated melanocytic cells or apoptosisassociated PARP cleavage, were not increased by antisense cyclin D1 transduction. Our data suggests that targetting cyclin D1 inhibition suppresses melanoma tumorigenicity by promoting a cytostatic differentiation-independent pathway, mediated by activation of $\mathrm{p} 53$ and anti-oxidant functions.
\end{abstract}

Keywords: p53/p21 pathway; anti-oxidant enzymes; growth retardation

\section{Introduction}

Normal human diploid fibroblasts can undergo replicative senescence after a finite number of doublings in culture concurrently with increased expression of a senescenceassociated $\beta$-galactosidase active at $\mathrm{pH} 6.0$, with no comparable behavior in malignant cells, which are immortal under similar conditions. ${ }^{1}$ Both the tumor suppressor p53 protein $^{2-4}$ and the cyclin-dependant kinase inhibitor p21WAF1 are also important in senescence, ${ }^{5}$ and cell cycle progression. $^{6-8}$ In particular, $\mathrm{p} 53$ has been recently implicated in the transcriptional induction of redox-related genes involved in the processing of reactive oxygen species. ${ }^{9}$ Reactive oxygen species are also known to play a role in regulating senescence ${ }^{10}$ and malignancy. ${ }^{11}$ Increased expression of anti oxidant enzymes like $\mathrm{Cu} / \mathrm{Zn}$ Superoxide Dismutase (Cu/Zn SOD), ${ }^{12}$ and Manganese superoxide dismutase (Mn SOD), ${ }^{13}$ has been associated with suppression of tumorigenicity and metastatic ability. Senescence is also partly regulated by $\mathrm{p} 16 \mathrm{INK} 4 \mathrm{~A}$, a cyclin-dependent kinase inhibitor of the cyclin $\mathrm{D} / \mathrm{cdk} 4 / \mathrm{Rb}$ pathway, which drives the G1 to S-phase progression of the cell cycle. ${ }^{14,15}$ However, the p16-cyclin D-cdk 4-pRB pathway is frequently altered ${ }^{16}$ or inactivated ${ }^{17}$ in most melanoma tumors. Nevertheless, downregulation of this pathway concurrently with a decrease in cyclin D1 is detected in B16 melanoma undergoing terminal differentiation and replicative senescence. ${ }^{18,19}$ The latter results suggest a mutually exclusive interplay between differentiation and proliferation, ${ }^{20}$ in which malignancy is usually associated with cyclin D1 overexpression. ${ }^{19,21}$ Here we show that targeted decrease of cyclin D1 expression by introduction of an antisense cyclin D1 sequence 22 into undifferentiated K1735 melanoma cells, ${ }^{23}$ induces loss of in vivo tumorigenicity, reversal of immortalization, increase in senescence-associated $\beta$-galactosidase ${ }^{1}$ and induction of $\mathrm{p} 53^{2-4}$ and $\mathrm{p} 21 \mathrm{WAF}^{5}$ like that seen in senescent diploid cells. We also demonstrate that targeted decrease of cyclin D1 by an antisense to cyclin D1 also leads to an elevation of Superoxide Dismutases relative to Peroxidases, like that seen in cellular senescence. ${ }^{24}$ However, reversal of tumorigenicity by an antisense cyclin D1 cDNA, which activates the p53p21WAF1 pathway and restores anti-oxidant activities, occurs without apparent cell death or concomitant increase in pigmentation or tyrosinase expression in K1735 melanoma cells, which are properties characteristic of melanocytic cell differentiation. ${ }^{18}$ Our findings imply that in vivo and in vitro growth suppression of tumors refractory to differentiation ${ }^{25}$ can occur independently of increased differentiation ${ }^{20}$ and without cell death by induction of tumor growth retardation ${ }^{26}$ mediated by an increase in p53 and superoxide dismutases.

\section{Results}

Loss of in vitro proliferative capacity and in vivo tumorigenicity by transduction of an antisense to cyclin D1 in differentiation-refractory K1735 melanoma

Prior studies have demonstrated lung cancer cell retardation $^{26}$ or induction of growth arrest in colonic tumors by antisense to cyclin D1. ${ }^{22}$ Since we previously demonstrated 
suppression of growth and tumorigenicity concurrent with down-regulation of cyclin D1 by L-tyrosine induction of terminal differentiation in partly pigmented B16 melanoma, ${ }^{19}$ we investigated whether a similar response occurred after antisense cyclin D1 gene transfer ${ }^{22}$ in K1735 melanoma refractory to differentiation. Attempts to obtain surviving cells after introduction of this plasmid into pigmented B16 melanoma completely failed, since cells became terminally differentiated ${ }^{18,19}$ and could not be subcultured (not shown). In contrast to B16 melanoma which responded to $1 \mathrm{mM} \mathrm{L}$ tyrosine by undergoing terminal growth arrest and increasing pigmentation, $\mathrm{K} 1735$ cells which are unpigmented ${ }^{23}$ failed to show a comparable response after transduction with antisense to cyclin D1 or with control vector (Figure 1). Neo resistant cells K1735 surviving cells obtained after retroviral transduction with control or antisense cyclin D1 retroviral pMV7neo vector, were pooled to examine the effects of antisense cyclin D1 on these melanoma tumors unresponsive to pigmentation-inducing agents. By comparative immune precipitation with antibody to cdk4 and replica Western blotting vs cdk4 or p16, K1735 cells behaved like most melanoma lines in which p16 is non-functional, ${ }^{17}$ by failing to show p16 protein binding to $\operatorname{cdk} 4,{ }^{17}$ in contrast to that detected under comparable conditions with similar levels of cdk4 protein (not shown) in normal Melan A melanocytes. ${ }^{19}$ After retroviral transduction of the antisense to cyclin D1, K1735 cultures yielded slow-growing neomycin-resistant cells, with a doubling time of approximately $65 \mathrm{~h}$ within the first 4-6 in vitro passages compared to a doubling time of only $24 \mathrm{~h}$ of the same cells transduced with the same vector lacking the antisense cyclin D1 gene (Table 1). In spite of the common lack of pigmentation in response to tyrosine, K1735 cells harboring the empty neo vector grew in dense multilayers, showing a typical malignant morphology. In contrast, multilayers were not seen in K1735 cells harboring the antisense to cyclin D1, which showed lower cell density, increased cell-cell interaction, and greater flattening on their substratum (Figure 1). This different morphology of cells transduced with anticyclin D1 was paralleled by a much slower replicative potential following clonal expansion, even when cultures were provided with $5-20 \%$ serum, including EGF or FGF supplements in the $2-50 \mathrm{ng} / \mathrm{ml}$ range. $^{18}$ In parallel with the morphological changes seen in Figure 1, detection of the senescence-associated $\beta$-galactosidase activity at $\mathrm{pH} 6.0^{13}$ was also increased from 4 to around $37 \%$ in cells transduced with antisense to cyclin D1 (Table 1). Also, in vivo tumorigenic ability was completely suppressed in the latter cells, in contrast with no comparable suppression in control cells transfected with the empty plasmid (Table 1).

\section{Antisense to cyclin D1 promotes binding of p27kip1 to Cyclin A and decreases Rb phosphorylation}

We compared the effect of introducing the antisense to cyclin D1 on the expression of several cell cycle regulatory proteins by immune blotting with well characterized specific antibodies. Cell lysates were prepared from control cells transduced with the neo resistance pMV7 plasmid, and from cells transduced with the pMV7D1AS plasmid in which the antisense to cyclin D1 was inserted into the vector. ${ }^{22}$ These experiments revealed that cyclin D1 was preferentially decreased in cells transduced with antisense to cyclin D1, with no comparable effects on cyclin D3 or cdk4. This was associated with an increase in the slow-migrating, hypophosphorylated form of the Retinoblastoma $\mathrm{Rb}$ protein, in contrast to the preferential expression of upper hyperphosphorylated $\mathrm{Rb}$ in control cells (Figure 2). Similar results were recently reported for colon cancer cells also transduced with antisense to cyclin D1. ${ }^{22}$

Since p27 KIP1 interacts with cyclin D1-cdk4 complexes, ${ }^{27}$ we also investigated whether cells harboring the
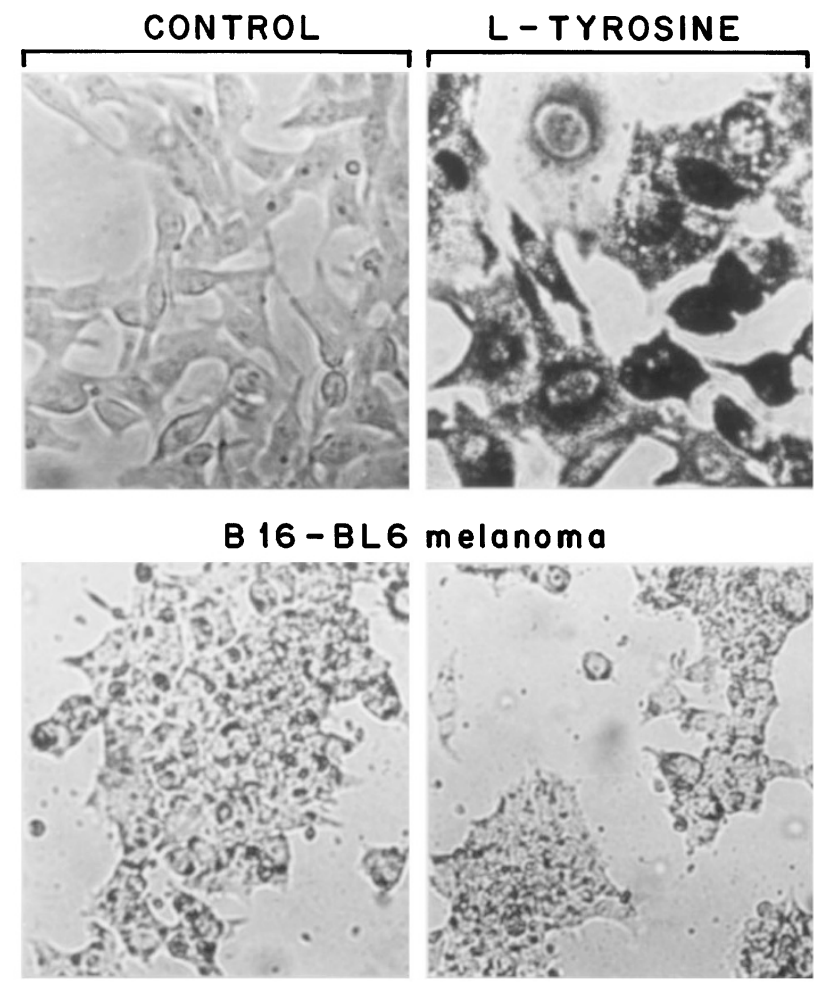

K1735 melanoma (antisense cyclin D1)
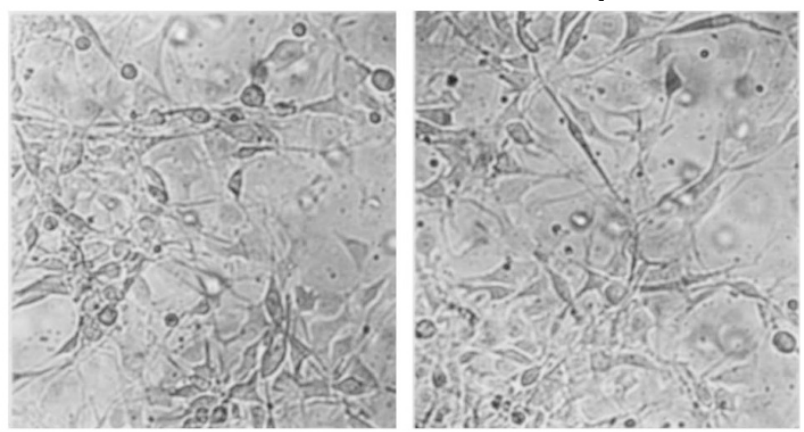

K1735 melanoma (vector)

Figure 1 Lack of response to differentiation-inducers persists after antisense cyclin D1 gene transfer in K1735 melanoma. B16-BL6 melanoma which increase melanocytic-specific pigmentation after a 2 day exposure to $1 \mathrm{mM} \mathrm{L-}$ tyrosine, were used as a positive control (upper, right) to examine a comparable response in either $\mathrm{K} 1735$ melanoma transduced with antisense to cyclin D1 (middle), or the same cells transduced with control vector (lower) 
Table 1 Suppression of in vivo and in vitro K1735 tumor growth by transfection of antisense cyclin D1

\begin{tabular}{lll}
\hline & Control & $\begin{array}{l}\text { Cyclin D1 } \\
\text { antisense }\end{array}$ \\
\hline Doubling time & $24 \mathrm{~h}$ & $65 \mathrm{~h}$ \\
Cell doublings after 6 days & $>5.5$ & $2.2 \pm 0.4$ \\
$\begin{array}{c}\text { Cell density after } 5 \text { days with } \\
\text { comparable initial inoculum }\end{array}$ & $\begin{array}{c}2.8 \times 10^{6} \pm 0.2 \\
\text { per } 35 \mathrm{~mm} \text { well }\end{array}$ & $\begin{array}{l}0.8 \times 10^{6} \pm 0.1 \\
\text { per } 35 \mathrm{~mm} \text { well }\end{array}$ \\
$\begin{array}{c}\text { Colony formation in agar (\%) } \\
5 \pm 1.7\end{array}$ & 0 \\
$\begin{array}{c}\text { Tumor formation in syngeneic } \\
\quad 7 / 7\end{array}$ & $0 / 7$ \\
$\begin{array}{c}\text { C3H mice } \\
\text { Senescence-associated }\end{array}$ & $4.1 \pm 1.3$ & $37.9 \pm 3.5$ \\
$\beta$-galactosidase & & \\
$\mu$ melanin per million cells & $0.048 \pm 0.01$ & $0.052 \pm 0.01$ \\
\hline
\end{tabular}

Control K1735 $\left(2 \times 10^{5}\right.$ cells) obtained after transduction with control retroviral pMV7neo plasmid were assayed in $\mathrm{C} 3 \mathrm{H}$ mice, forming evident footpad tumor after 4-5 weeks. No comparable tumor formation was evident with a similar number of cells transducted with the pMV7 D1AS cyclin D1 antisense neo plasmid by 12 weeks. Colony formation in agar was carried out as indicated, ${ }^{22}$ and senescenceassociated $\beta$-galactosidase $\mathrm{pH} 6.0$ was assayed. ${ }^{3}$ Cell culture assays were performed in triplicate which agreed within $7 \%$, and animal experiments used triplicates of seven mice per assay

antisense to cyclin D1 differed from control cells in p27 KIP1-cyclin-cdk interactions. Immune precipitation with antibody to p27 KIP1 followed by electrophoretic analysis and immune blotting revealed cyclin D1 and cdk4 association with p27 KIP1 in control cells as reported for growing Swiss 3T3 cells. $^{27}$ In contrast complex formation between either p27 KIP1 and cyclin A or p27KIP1 and cdk2, was preferentially evidenced in cells transduced with antisense to cyclin D1 (Figure 3). This resembles the increased association of cyclin A with p27KIP1 reported in anti-IgM induced grown arrest of WEHI-23 B cell lymphoma. ${ }^{28}$

\section{p21WAF1 mRNA and expression of p53 and p21WAF1 proteins are induced by antisense to cyclin D1 without an increased in differentiation- associated tyrosine}

Since the tumor suppressor $\mathrm{p5}^{2-4}$ and the cyclin-dependent kinase inhibitor p21WAF1 $1^{5-8}$ are also important in senescence, tumorigenesis and cell cycle progression, we also investigated whether expression of these proteins and their mRNAs differed in cells unequally expressing cyclin D1. Since Northern blots required high amounts of total RNA and cells transduced with antisense to cyclin D1 grew very slowly, we used RT - PCR to investigate mRNA levels of p53, p21WAF1, as well as those of tyrosinase, which is an initial limiting step in melanocytic cell pigmentation, ${ }^{18}$ for comparison with a usually constitutive gene like GAPDH. ${ }^{12}$ These experiments revealed comparable mRNA levels of p53, tyrosinase and GAPDH in K1735 control melanoma and those harboring an antisense cyclin D1. However, the latter cells showed a selective increase in p21WAF1 mRNA compared to that of control RNA (Figure 4, left).

We also investigated whether protein expression of p53 and p21WAF1 and tyrosinase (Figure 4, right) were influenced by transduction of an antisense to cyclin D1.

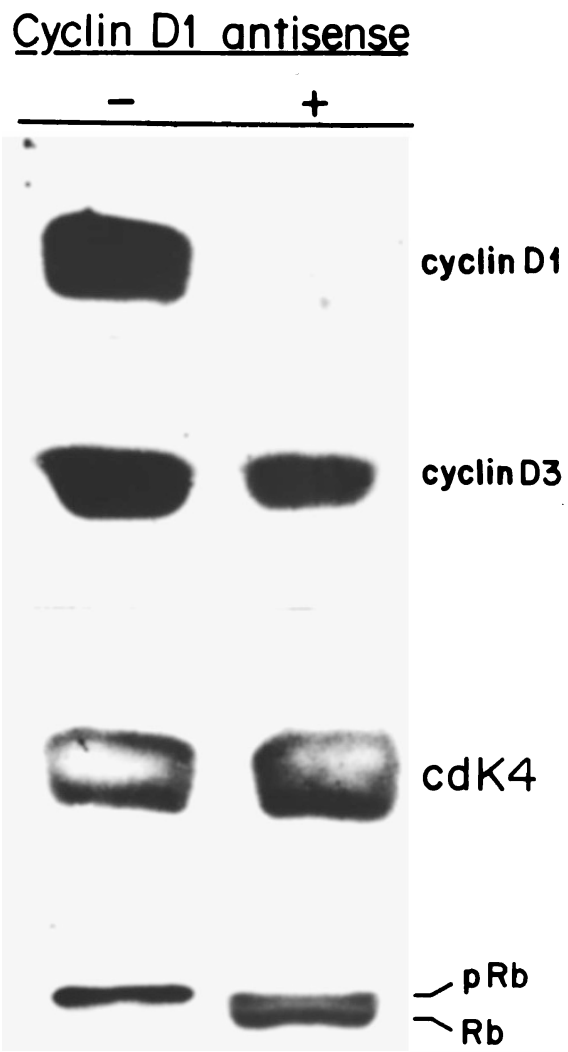

Figure 2 Decrease in cyclin D1 is reciprocal with expression of hypophosphorylated $\mathrm{Rb} .100 \mu \mathrm{g}$ cellular protein from each cell extract was used in immune blot analysis of control K1735 cells transduced with pMV7, or those transduced with anti cyclin D1 pMV7D1 AS (antisense). Note down regulation of cyclin D1 reciprocal with increase in lower non-phosphorylated $\mathrm{Rb}$ band

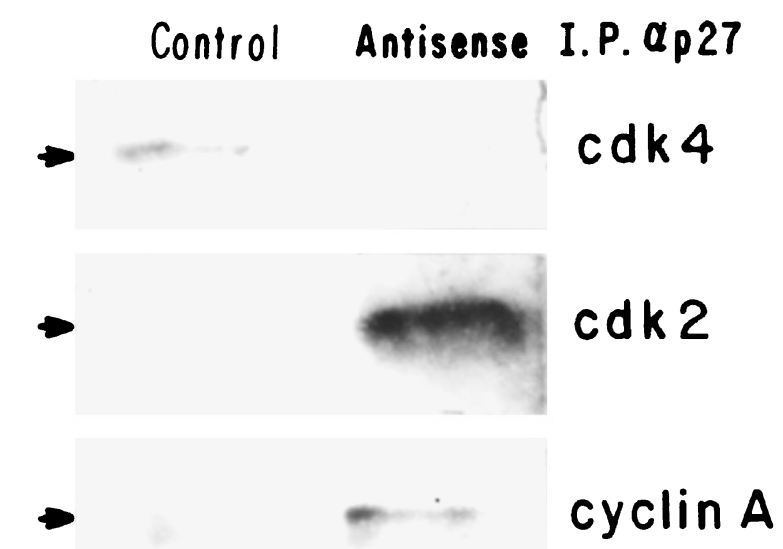

\section{cyclin D 1}

Figure 3 p27KIP1 complex with cyclin A and cdk2 is increased in cells expressing the antisense to cyclin D1. $200 \mu \mathrm{g}$ cellular protein were used for immune precipitation with antibody to p27KIP1, followed by Western blot with cdK4, cdK2, cyclin A or Cyclin D1. Note increased p27 complex formation with cyclin A and cdk2 in cells transduced with antisense to cyclin D1 
In agreement with reports showing that senescent cells express more $\mathrm{p} 53,^{2,4}$ we also observed increased expression of p53 protein in K1735 cells with limited replicative ability obtained by transduction of antisense to cyclin D1. This was paralleled by concomitant induction of p21WAF1 protein, whose expression is known to be activated by $p 53^{6-8}$ and induced in senescent cells. ${ }^{5}$ However, increases in p53 and p21WAF1 protein by antisense cyclin D1 gene transfer, were not paralleled by increases in pigmentation-associated melanin (Table 1) or tyrosinase expression ${ }^{18}$ which remained similar both at the mRNA and protein levels in cells transduced with control or antisense cyclin D1 gene (Figure 4).

\section{Superoxide dismutases but not glutathione peroxidase or catalase are increased in cells transduced with antisense to cyclin D1}

Reactive oxygen plays a major role in the aging process, ${ }^{10} \mathrm{Mn}$ superoxide dismutase expression is inversely correlated with metastatic ability ${ }^{13}$ and an elevation in the ratio of $\mathrm{Cu} / \mathrm{Zn}$ superoxide dismutase to glutathione peroxidase has been recently correlated with senescence. ${ }^{24}$ Hence, we compared the expression of several anti oxidant enzymes in control tumorigenic, immortal cells and in those in which tumorigenicity and replicative ability was suppressed by introduction of antisense to cyclin D1. This also revealed an elevation in superoxide dismutases compared to that of glutathione peroxidase and catalase (Figure 5), similar to that seen in senescent fibroblasts. ${ }^{10,24}$

\section{PARP cleavage is not increased by antisense cyclin D1 gene transfer}

Since K1735 melanoma transduced with antisense cyclin D1 failed to form in vivo tumors and colonies in agar, showing also a much slower proliferation in tissue culture, we investigated whether this was associated with increased PARP cleavage, which frequently correlates with apoptosis. ${ }^{29}$
For this, we compared adherent $\mathrm{K} 1735$ cells transduced with either control vector or with the vector harboring the antisense cyclin D1 gene, as shown in Figure 1. Immune blots with a PARP antibody which recognizes the intact molecule and the $85 \mathrm{kd}$ fragement frequently cleaved during apoptosis, revealed a comparable amount of both species in cells transduced with antisense cyclin D1 or control vector (Figure 6). As a positive indicator of apoptotic response, we used control cells analyzed $24 \mathrm{~h}$ after exposure to $25 \mathrm{~J} / \mathrm{m}^{2}$, which showed an increase in the lower $85 \mathrm{kd}$ form (Figure 5). These experiments imply that the effects of antisense cyclin D1 leading to K1735 tumor suppression do not involve extensive PARP fragmentation. ${ }^{29}$

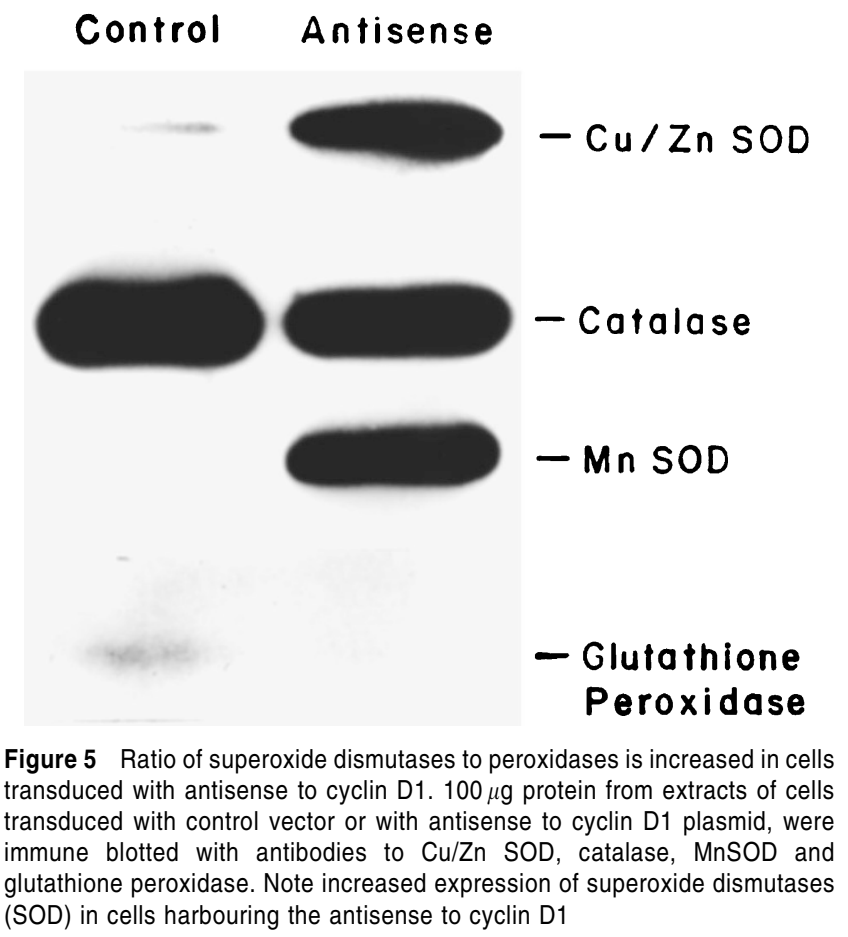

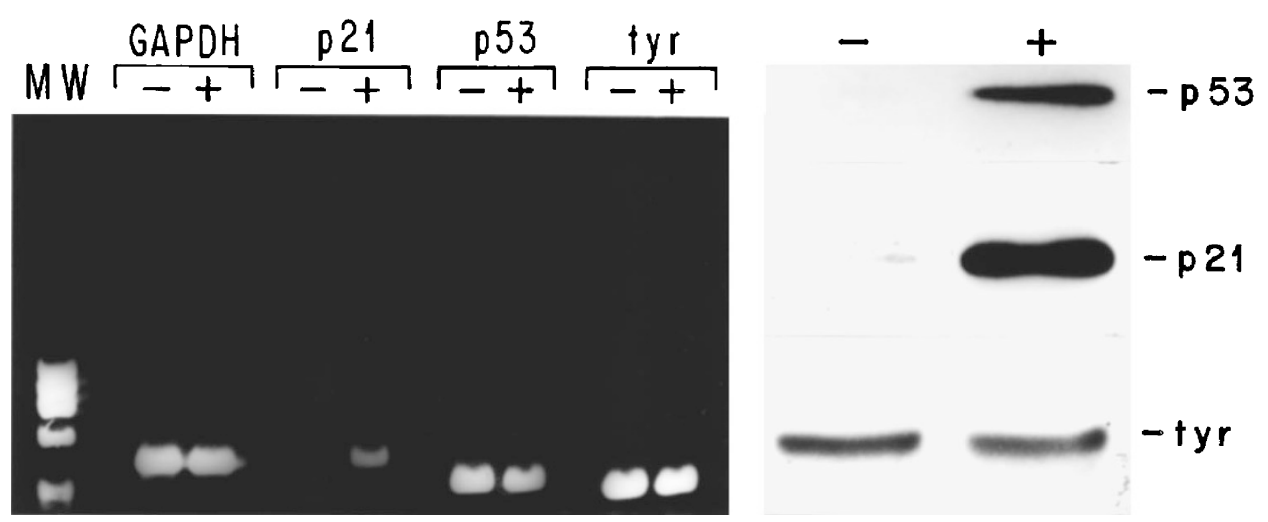

Figure 4 Increase in p21WAF1 mRNA and protein correlated with Induction of p53 protein in cells transduced with antisense to cyclin D1. (Left) Reverse transcription was carried out with $2 \mu \mathrm{g}$ total RNA from cells transduced with control vector $(-)$ or antisense to cyclin D1 (+), and 1/10 ${ }^{\text {th }}$ of this was used for PCR with primers specific for GAPDH, p21WAF1, p53 and tyrosinase. Note selective increase in p21WAF1 mRNA in cells transduced with antisense to cyclin D1. No bands were obtained in RNA samples without reverse transcriptase, implying lack of contaminating DNA in PCR. (Right) Immune blot of p53 with PAB 421 antibody and p21WAF1 with antibody SC-397 and Pep 7 antibody vs tyrosine. Note increase p53 and p21WAF1 protein expression in cells transduced with antisense to cyclin D1, at comparable levels of tyrosinase in control cells 


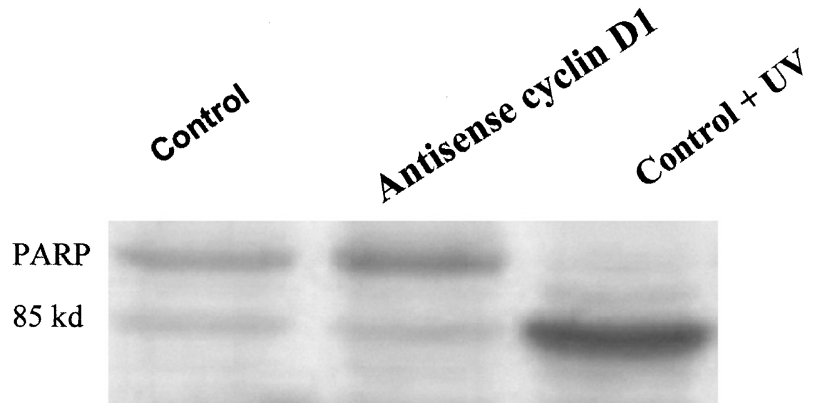

Figure 6 PARP cleavage is not increased by antisense cyclin D1 gene transfer. $100 \mu \mathrm{g}$ protein from extracts of untreated (control), UV-treated (25 J/ $\mathrm{m}^{2}$ ) cells transduced with control vector, or those transduced with antisense to cyclin D1, were immune blotted with antibody (SC-7150) to PARP protein Note increased expression of $85 \mathrm{kd}$ PARP fragment in UV-treated cultures, and similar levels of undegraded PARP in untreated control cells and those harboring the antisense to cyclin D1

\section{Discussion}

We have now demonstrated that decreasing cyclin D1 expression by introduction of an antisense cyclin D1 gene leads to in vivo loss of tumorigenicity and to a diminished in vitro replicative ability in K1735 melanoma. These properties were paralleled by a relative increase in the non-phosphorylated tumor suppressive form of $\mathrm{Rb},{ }^{22}$ and by an increased binding of the cdk inhibitor p27 KIP1 to cyclin A and cdk2, ${ }^{28}$ properties known to be associated with growth arrest, since they decrease the ability of cells to enter S-phase. ${ }^{28}$ Although senescent normal fibroblasts do not express cyclin $A,{ }^{30}$ a number of tumor cells fail to down-regulate cyclin $A$ with serum starvation ${ }^{31,32}$ or terminal differentiation, ${ }^{33}$ even those transduced with antisense to cyclin D1 (Figure 3). However, the aberrantly regulated cyclin A pathway of malignant cells ${ }^{31-33}$ can be bypassed in the latter cells by suppressing tumor growth through down-regulation of cyclin D1. Although our results are compatible with prior studies showing lung cancer cell retardation ${ }^{26}$ or induction of growth arrest in colonic tumors by antisense to cyclin $\mathrm{D} 1,{ }^{22}$ we are the first to show that suppression of growth and tumorigenicity by antisense cyclin D1 gene transfer occurs without reacquisition of cell-specific differentiation ${ }^{18}$ in K1735 melanoma. ${ }^{23}$ However, the shortened life span now observed after antisense cyclin D1 gene transfer into K1735 melanoma, resembled that obtained by L-tyrosine induction of terminal differentiation which also decreased cyclin D1 without affecting cyclin A in differentiation-proficient B16 melanoma. ${ }^{19}$ Moreover, our data shows that antisense cyclin D1 increases expression of senescence-associated $\beta$-galactosidase ${ }^{1,3}$ concurrently with induction of $\mathrm{p} 53,{ }^{2,4}$ and $\mathrm{p} 21 \mathrm{WAF} 1^{5}$ in K1735 melanoma cells, independently of inducing tyrosinase-associated differentiated properties. ${ }^{18}$ RT-PCR showed induction of p21WAF1mRNA without increase in p53 mRNA in K1735 transduced with antisense cyclin D1, in agreement with data comparing senescing with young fibroblasts. $^{2}$ However, p53 protein and p21WAF1 protein were both increased in K1735 transduced with antisense cyclin D1, results similar to those reported for normal fibroblasts induce to senesce by oncogenic H-Ras V-12. ${ }^{3}$
These results suggest that the tumor suppressive effects of introducing an antisense cyclin D1 gene into K1735 (Table 1) are partly mediated by activation of the p53/p21WAF1 pathway. ${ }^{6}$

Another novel change detected in K1735 melanoma cells transduced with antisense to cyclin D1 was an increase in anti-oxidant enzymes concurrent with suppression of immortalization and tumorigenicity. This was reflected by an increased expression of $\mathrm{Cu} / \mathrm{Zn}$ superoxide dismutase $^{12}$ and $\mathrm{Mn}$ superoxide dismutases ${ }^{13}$ but not of glutathione peroxidase or catalase. Overexpression of superoxide dismutases has been shown to suppress the melanoma malignant phenotype. ${ }^{13}$ Also, a similar elevation in the ratio of dismutases to peroxidases like that seen in cells transduced with antisense to cyclin D1, has been correlated with senescence features in human cells. ${ }^{24}$ To our knowledge, this is the first study linking antisensemediated suppression of cyclin D1 expression ${ }^{22}$ with concomittant increases in specific anti-oxidant enzymes and activation of the p53/p21 pathway without hypoxia ${ }^{34}$ or genotoxic damage. ${ }^{6-8}$ It was recently demonstrated in melanomas that accumulation of p53 in S-phase during hypoxia was not related to hypoxia-induced apoptosis. ${ }^{34}$ This is compatible with the present data showing lack of PARP cleavage with p53 overexpression in cells transduced with anti cyclin D1, which also revealed induction of superoxide dismutases. The latter is also compatible with reports that p53 not only induces genes like p21WAF1 but also activates genes implicated in anti-oxidant functions. ${ }^{9}$ Increase in anti-oxidant enzymes like $\mathrm{Cu} / \mathrm{Zn}$ superoxide dismutases like that seen in anti-cyclin D1 transduced melanoma has also been recently described in aged cells of a transgenic model for Alzheimer's disease. ${ }^{35}$ Recent results have demonstrated that virtually $100 \%$ of melanoma cell lines have a non-functional p16INKa gene ${ }^{36}$ extending prior findings in cultured melanoma cells and primary tumors. ${ }^{16,17}$ Such reports are in agreement with our own functional observations (not shown) that K1735 melanoma resemble most melanoma lines by failing to show functional p16 protein binding to cdk4, ${ }^{17,36}$ in contrast to that seen under comparable conditions in normal melanocytes (not shown). Nevertheless, our data suggest an alternative modulation of the p16 INK4A-cyclin D1-cdk 4-Rb pathway via antisense cyclin D1 as a cytostatic option to slow the proliferation and suppress the in vivo tumorigenicity of K1735 melanoma. The effect of antisense cyclin D1 to induce growth suppression and acquisition of properties partly associated with a senescent phenotype in differentiation-refractory K1735 melanoma, extends our prior findings demonstrating acquisition of a senescence-like growth arrest in B16 melanoma, when cyclin D1 is alternatively down-regulated after induction of terminal differentiation in B16 melanoma. ${ }^{18,19}$ Our data showing inhibition of replicative ability (Table 1 ) with loss of cyclin D1, represents a cytostatic alternative to learn about negative control mechanisms different from terminal differentiation or apoptosis. Lack of cell death in anticyclin D1 transduced K1735 cells was assessed by their ability to attach and remain flattened on their substrate for weeks (Figure 1), by their ability to exclude trypan blue (not shown) and by their 
lack of apoptosis-associated PARP cleavage ${ }^{29}$ (Figure 6). Whereas apoptosis may involve activation of deathinducing genes, ${ }^{29}$ antisense cyclin D1 appears to decrease proliferation and supress tumorigenicity partly by activating expression of the p53 protein without any additional stress. Induction of p53 in K1735 melanoma via down-regulation of cyclin D1 is novel, since the p53 protein is unstable in proliferating cells, ${ }^{3,34}$ and known to be stabilized by genotoxic stress, ${ }^{6-8}$ hypoxia $^{34}$ or by oncogenic ras induction of senescence in normal fibroblasts. ${ }^{3}$ Hence, joint induction of the p53 protein and the cdkinhibitor p21WAF1, with concomitant induction of superoxide dismutases, also known to suppress malignancy ${ }^{9-13}$ are involved in the mechanism of growth arrest without differentiation or apoptosis in anticyclin D1 transduced cells. Further studies should be carried out to define the reason why cyclin D1 decreases are common for growth inhibition in differentiation-proficient B16 melanoma ${ }^{37}$ and differentiation-refractory $\mathrm{K} 1735$ melanoma, ${ }^{23}$ since both are known to harbor wt p53 inducible by stress. ${ }^{23,37}$

In tumors like melanomas, in which the cyclin D1/Rb control pathway is impaired because of a frequently inactivated p16 INK4A tumor suppressor gene, ${ }^{17,36}$ targeted down-regulation of cyclin D1 may compensate for a defective p16 INK4A gene ${ }^{34}$ by alternative activation of the p53/p21WAF1 pathway and basal superinduction of superoxide dismutases. In support of our findings of a inverse relationship between cyclin D1 and p53 in K1735 cells, we recently demonstrated that UV concomitantly induced p53 and $\mathrm{Cu} / \mathrm{Zn}$ superoxide dismutase with a reciprocal decrease in cyclin D1 in other melanomas. ${ }^{12.37}$ The latter findings imply a reciprocal relationship between high p53 and low cyclin D1 in melanomas exposed to UV irradition, although the present studies suggest that cyclin D1 down-regulation favors overexpression of basal p53 protein, even without genotoxic stress. ${ }^{6-8}$ Recently, cyclin D1 overexpression was demonstrated in $65 \%$ of uveal melanoma biopsies, emphasizing the relevance of cyclin D1 in this tumor type. ${ }^{38}$ This further suggests that antagonizing expression of cyclin D1, ${ }^{19,21}$ may be important to control or revert a number of changes associated with multi-stage melanoma progression (Table 1).

Considering that the p16-cyclin D.cdk4 pathway is usually non-functional in melanoma tumors, ${ }^{16,34}$ and the lower cyclin D1 protein expression in non-proliferating melanocytes than in melanomas, ${ }^{19,38}$ our data also suggests that use of melanocyte-specific promoters ${ }^{39}$ preceding an antisense cyclin D1 sequence could provide the basis for a targeted retroviral vector potentially helpful against melanomas refractory to differentiation ${ }^{25}$ and other traditional therapies.

\section{Materials and Methods}

\section{Cells}

K1735 unpigmented melanoma were isolated originally and passaged in $\mathrm{C} 3 \mathrm{H}$ mice. ${ }^{23}$ Intravenous injection of 50000 cells per mice, yielded 20-30 lung colonies, using cells transfected with control pMV7 plasmid, vs no lung colonies in the same cells transfected with antisense to cyclin D1 pMV7 D1AS in pMV7 plasmid. ${ }^{22}$ Also, foot-pad s.c. injection of 75000 cells transfected with control plasmid produced a detectable tumor without 5-6 weeks, with no comparable tumor evident by 14 weeks in cells transduced with the antisense to cyclin D1 (Table 1).

\section{Retroviral transduction}

The pMV7 control or antisense to cyclin D1 pMV7 D1AS were cultured in E. coli cells, and the purified plasmid DNA samples $(10 \mu \mathrm{g})$ were transfected with lipofectin $(10 \mu \mathrm{g})$ (GIBCO-BRL) into GPAM 12 cells to generate defective retroviral particles. ${ }^{22}$ The viral supernatants were harvested and used to transduce either pigmentation-inducible B16 melanoma ${ }^{18}$ or unpigmented K1735 melanoma. ${ }^{23}$ Only the latter yielded surviving neomycin-resistant cells selectable with G418 geneticin $(0.6 \mathrm{mg} / \mathrm{ml})$, which were subsequently demonstrated to have the neo ${ }^{r}$ gene by Southern blot (not shown). Down-regulation of cyclin D1 in these cells was confirmed by immune blotting. Experiments to be described with cells transduced with antisense to cyclin D1 plasmid of control vector, were carried out within 2-3 passages of selection of neor cultures, after primary clonal expansion.

\section{Reverse transcription - PCR}

DNAse-treated total RNA $(2 \mu \mathrm{g})$ from control or antisense-transduced cells was reverse-transcribed with SuperScript II reverse transcriptase with oligo dT for $60 \mathrm{~min}$ at $42^{\circ} \mathrm{C}$. One tenth of the corresponding cDNA was used for specific hot-start PCR $\left(95^{\circ} \mathrm{C}\right.$ for $\left.5 \mathrm{~min}\right)$, and adding cDNA for 30 cycles at $94^{\circ} \mathrm{C}$ for $45 \mathrm{~s}, 58^{\circ} \mathrm{C}$ for $45 \mathrm{~s}$ and $72^{\circ} \mathrm{C}$ for $2 \mathrm{~min}$, followed by $7 \mathrm{~min}$ at $72^{\circ} \mathrm{C}$. GADPH and p53 primers used for PCR were from Clontech (Palo Alto, CA, USA). For p21WAF1, forward primers covered from nucleotide $80-108$ and the reverse primer from nucleotide 584-560. These primers and those for the first exon of the tyrosinase gene used as control for melanocytic cells ${ }^{33}$ were obtained from Genosys (Houston, Texas, USA).

\section{Immune blotting}

Extracts were prepared and immune blotted as described elsewhere. ${ }^{32}$ For Western blotting, detection of p53 was carried out with either antibody PAB 421 and PAB 240 from Oncogene Science. We also used C-19 antibody to the $C$ terminal domain of p21 WAF1 (SC397), antibody to p27 KIP 1 (SC-528), antibody to Rb (SC-102), antibody to cyclin D3 (SC-182), and antibody to PARP (SC-7150) were obtained from Santa Cruz Biotechnology, Santa Cruz, California. We thank Dr. Larry Oberley, University of lowa, for antibodies to either Mn or Cu/Zn Superoxide dismutases, Dr. M Pagano, (NY University, USA) for antibodies to cyclin D1, cdk2 and cdk4, Dr. Greg Hannon (Cold Spring Harbor Laboratory, NY, USA) for antibody to p16, and Dr. Vincent J Hearing, (National Institutes of Health, Bethesda, MD, USA) for antibody to tyrosinase. After reaction with primary antibodies, blots were reacted with the corresponding species-specific secondary antibodies, followed by detection with ECL chemiluminescence (Amersham).

\section{Senescence-associated $\beta$-galactosidase}

This was assayed after washing cells in PBD, fixation in $0.5 \%$ glutaraldehyde in PBS pH 7.2 washing in PBS with $1 \mathrm{mM} \mathrm{MgCl}$, staining with $1 \mathrm{mg} / \mathrm{ml} \mathrm{X-gal} \mathrm{(Gibco-BRL),} 0.12 \mathrm{mM} \mathrm{K} \mathrm{K}_{4} \mathrm{Fe}(\mathrm{CN})_{6}$, $\mathrm{K}_{4} \mathrm{Fe}(\mathrm{CN})_{6}, 1 \mathrm{mM} \mathrm{Mgcl} 2$ in PBS pH 6.0 (3). Staining was allowed to 
proceed for $16 \mathrm{~h}$ at $37^{\circ} \mathrm{C}$ in the absence of $\mathrm{CO}_{2}$, to maintain $\mathrm{pH} 6.0$ during $\beta$-gal staining.

\section{Acknowledgements}

We appreciate the generosity of Dr. IB Weinstein, (Columbia-Presbiterian Cancer Center, NY) in providing us with plasmids pMV7 and pMV7D1AS. The financial support of CONICIT through Grants G 97-000613 and S196001340 is greatly appreciated.

\section{References}

1. Dimri GP, Lee X, Basile G, Acosta M, Scott G, Roskelley C, Medrano EE, Linskens M, Rubelj I, Pereira-Smith O, Peacocke M and Campisi J (1995) A biomarker that identifies senescent human cells in culture and in aging skin in vivo. Proc. Natl. Acad. Sci. USA 92: 9363-9367.

2. Atadja $P$, Wong $H$, Garkavtsev I, Veillette $C$ and Riabowol K (1995) Increased activity of p53 in senescing fibroblasts. Proc. Natl. Acad. Sci. USA 92: $8348-$ 8352.

3. Serrano M, Lin AW, McCurrach ME, Beach D and Lowe SW (1997) Oncogenic ras provokes Premature Cell Senescence Associated with Accumulation of p53 and p16 INK4A. Cell 88: 593-602.

4. Sugrue MM, Shin DY, Lee SW and Aaronson SA (1997) Wild type p53 triggers a rapid senescence program in human tumors lacking functional p53. Proc. Natl. Acad. Sci. USA 94: 9648-9653.

5. Noda A, Ning Y, Venable SF, Pereira-Smith OM and Smith JR (1994) Cloning of senescent cell-derived inhibitors of DNA synthesis using an expression screen. Exp. Cell Res. 211: 90-98.

6. El Deiry WS, Tokino T, Velculescu VE, Levy DB, Parsons R, Trant JM, Lin D, Lercer WE, Kinzler KW and Vogelstein BE (1993) WAF1, a potential mediator of p53 tumor suppressor. Cell 75: 817-825.

7. Harper JW, Adami GR, Wei N, Keyomarsi K and Elledge SJ (1993) The p21 Cdkinteracting protein $\mathrm{Cip} 1$ is a potent inhibitor of $\mathrm{G} 1$ cyclin-dependent kinases. Cell 75: 805-816.

8. Xiong Y, Hannon GJ, Zhang H, Casso D, Kobayashi Rand Beach D (1993) p21 is a universal inhibitor of cyclin kinase. Nature 366: 701-704.

9. Polyak K, Xia Y, Zweier JL, Kinzler KW and Vogelstein B (1997) A model for p53induced apoptosis. Nature 389: 300-305.

10. Chen Q and Ames BN (1994) Senescence-like growth arrest induced by hydrogen peroxide in human diploid fibroblast F65 cells. Proc. Natl. Acad. Sci. USA 91: $4130-4134$.

11. Oberley LW and Oberley TD (1988) Role of anti-oxidant enzymes in cell immortalization and transformation. Mol. Cell. Biochem. 84: 147-153.

12. Alvarez M, Strasberg Rieber M and Rieber M (1998) Chromosome 6-mediated Suppression of Metastatic ability increases basal expression of UV-inducible Superoxide Dismutase and p53. Int. J. Cancer 77: 586-591.

13. Church SL, Grant SW, Ridnour LA, Oberley LW, Swanson PE, Meltzer PS and Trent JM (1993) Increased manganese superoxide dismutase expression suppresses the malignant phenotype of human melanoma cells. Proc. Natl. Acad. Sci. USA 90: 3113-3117.

14. Alcorta DA, Xiong Y, Phelps D, Hannon G, Beach D and Barrett JC (1996) Involvement of the cyclin-dependent kinase inhibitor p16 INK4 ${ }^{\mathrm{a}}$ in replicative senescence of normal human fibroblasts. Proc. Natl. Acad. Sci. USA 93: 1374213747.

15. Uhrbom L, Nister M and Westermark B (1997) Induction of senescence in human malignant glioma cells by p16INI4A. Oncogene 15: 505-514.

16. Bartkova J, Lukas J, Guldberg G, Alsner J, Kirkin AF, Zeuthen J and Bartek J (1996) The p16-cyclin D/cdk 4-pRb pathway as a functional unit frequently altered in melanoma pathogenesis. Cancer Res. 56: 5475-5483.

17. Castellano M, Pollock PM, Walers MK, Sparrow LE, Down LM, Gabrielli BG, Parsons PG and Hayward NK (1997) CDK2A/p16 is inactivated in most Melanoma lines. Cancer Res. 57: 4868-4875.

18. Strasberg Rieber M and Rieber M (1993) Specific Tyrosinases associated with Melanoma Replicative Senescence and Melanogenesis. Cancer Res. 53: $2469-2471$
19. Strasberg Rieber M and Rieber M (1995) Suppression of Cyclin D1 but not cdk4 or Cyclin A with induction of Melanoma Terminal Differentiation. Biochem. Biophys. Res. Comm. 216: 422-427.

20. Olson E (1992) Interplay between proliferation and differentiation within the myogenic lineage. Dev. Biol. 154: 261-272.

21. Weinstat Saslow D, Merino MJ, Manrow RE, Lawrence JA, Bluth RF, Wittenbel KD, Simpson JF, Page DL and Steeg PS (1995) Overexpression of cyclin D mRNA distinguishes invasive and in situ breast carcinomas from non-malignant lesions. Nature Medicine 1: 1257-1260.

22. Arber N, Doki Y, Han EK, Sgambato A, Zhou P, Kim N-H, Delohery T, Klein MG, Holt PR and Weinstein IB (1997) Antisense to cyclin D1 inhibits the Growth and Tumorigenicity of Human Colon Cancer Cells. Cancer Res. 57: 1569-1574.

23. Xie K, Wang Y, Huang S, Xu L, Bielenberg D, Salas T, McConkey DJ, Jiang Wand Fidler IJ (1997) Nitric oxide-mediated apoptosis of K1735 melanoma is associated with down-regulation of bcl-2. Oncogene 15: 771-779.

24. de Haan JB, Cristiano F, lannello R, Bladier C, Kelner MJ amd Kola I (1996) Elevation in the ratio of $\mathrm{Cu} / \mathrm{Zn}$-superoxide dismutase to glutathione peroxidase activity induces features of cellular senescence and this effect is mediated by hydrogen peroxide. Human Mol. Gen. 5: 283-292.

25. Petersen W, Ronnov-Jessen L, Weaver VM and Bisell MJ (1998) Differentiation and cancer in the mammary gland-shedding light on an old dichotomy. Adv. Cancer Res. 75: 135-161.

26. Driscoll B, Wu L, Buckley S, Hall FL, Anderson KD and Warburton D (1997) Cyclin D1 antisense RNA destabilizes pRb and retards lung cancer cell growth. Am. J. Physiol. 273: L941-L949.

27. Toyoshima H and Hunter T (1994) p27, A novel inhibitor of G1 Cyclin-Cdk protein Kinase Activity, is related to p21. Cell 78: 67-74.

28. Ezhevsky SA, Toyoshima H, Hunter T and Scott SW (1996) Role of cyclin A and p27 in anti-lgM induced G1 growth arrest of murine B cell lymphomas. Mol. Biol. Cell. 7: 553-584.

29. Pieper AA, Verma A, Zhang J, Snyder SH (1999) Poly (ADP-ribose) polymerase, nitric oxide and cell death. Trends Pharmacol. Sci. 20: 171-181.

30. Stein GH, Drullinger LF, Robetorye RS, Pereira-Smith $O$ and Smith JR (1991) Senescent cells fail to express cdc2,cyc $A$ and cyc $B$ in response to mitogen stimulation. Proc. Natl. Acad. Sci. USA 88: 11012-11016.

31. Jansen-Durrer P, Meichle A, Steiner P, Pagano M, Finke K, Botz J, Wessbecher $J$, Draetta G and Eilers M (1993) Differential modulation of cyclin gene expression by MYC. Proc. Natl. Acad. Sci. USA 90: 3685-3688.

32. Barlat I, Fesquet D, Brechot C, Henglein B, Dupuy d'Angeac A, Vie A and Blanchard JM (1993) Loss of the G1-S control of cyclin A expression during tumoral progression of Chinese hamster lung fibroblasts. Cell Growth and Diff. 4 : $105-113$.

33. Rieber M and Strasberg Rieber M (1994) Cyclin-dependent kinase 2 and cyclin A interaction with $\mathrm{E} 2 \mathrm{~F}$ are targets for tyrosine induction of $\mathrm{B} 16$ melanoma terminal differentiation. Cell Growth and Diff. 5: 1339-1346.

34. Danielsen T, Hvidsten M, Stokke T, Solberg K, Rofstad EK (1998) Hypoxia induces p53 accumulation in the S-phase and accumulation of hypophosphorylated retinoblastoma protein in all cell cycle phases of human melanoma cells. Br. J. Cancer 78: 1547-1558.

35. Pappolla MA, Chyan YJ, Omar RA, Hsiao K, Perry G, Smith MA and Bozner P (1998) Evidence of oxidative stress and in vivo neurotoxicity of beta-amyloid in a transgenic mouse model of Alzheimer's disease: a chronic oxidative paradigm for testing antioxidant therapies in vivo. Am. J. Pathol. 152: 871-877.

36. Walker GJ, Flores JF, Glendening JM, Lin AH, MarkI ID and Fountain JW (1998) Virtually $100 \%$ of melanoma cell lines harbor alterations at the DNA level within CDKN2, CDKN2B, or one of their downstream targets. Genes Chromosomes Cancer 22: 157-163.

37. Rieber M and Strasberg Rieber M (1998) Induction of p53 and Melanoma Cell Death is reciprocal with Down-regulation of E2F, cyclin D1 andpRb. Int. J. Cancer 76: $757-760$.

38. Coupland SE, Bechrakis N, Schuler A, Anagnostopoulos I, Hummel M, Bornfield $\mathrm{N}$, Stein $\mathrm{H}$ (1998) Expression patterns of cyclin D1 and related proteins regulating G1-S phase transition in uveal melanoma and retinoblastoma. Br. J. Ophthalmol. 82: $961-970$

39. Vile RG, Diaz RM, Miller N, Mitchell S, Tuszyanski A and Russell SJ (1995) Tissue-specific Gene expression from Mo-MLV Retroviral Vectors with Hybrid LTRs containing the Murine Tyrosinase Enhancer/Promoters. Virology 214: 307-313. 